Modern Cost-Benefit Methods 


\section{Modern Cost-Benefit Methods}

An Introduction to Financial, Economic and Social Appraisal of Development Projects

\section{George Irvin}

with the assistance of Richard Brown

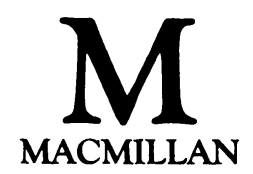


(C) George Irvin 1978

All rights reserved. No reproduction, copy or transmission of this publication may be made without written permission.

No paragraph of this publication may be reproduced, copied or transmitted save with written permission or in accordance with the provisions of the Copyright Act 1956 (as amended), or under the terms of any licence permitting limited copying issued by the Copyright Licensing Agency, 7 Ridgmount Street, London WC1E 7AE.

Any person who does any unauthorised act in relation to this publication may be liable to criminal prosecution and civil claims for damages.

First published 1978

Reprinted 1984, 1985, 1986, 1987

Published by

MACMILLAN EDUCATION LTD

Houndmills, Basingstoke, Hampshire RG21 2XS

and London

Companies and representatives

throughout the world

British Library Cataloguing in Publication Data

Irvin, George

Modern cost-benefit methods.

1. Cost effectiveness

I. Title

658.1'554 HD47

ISBN 978-0-333-23208-8

ISBN 978-1-349-15912-3 (eBook)

DOI 10.1007/978-1-349-15912-3

\section{to Jeannie and Marc}




\section{CONTENTS}

Introduction $\quad$ ix

Chapter I Principles of Project Appraisal and Selection 1

1.01 Stages of Project Planning 1

1.02 Alternatives, Enumeration and Quantification 4

$\begin{array}{ll}1.03 \text { Cash Flows } & 7\end{array}$

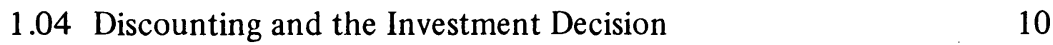

$\begin{array}{ll}1.05 \text { Inflation } & 14\end{array}$

1.06 The Internal Rate of Return (IRR) 14

$\begin{array}{ll}1.07 \text { NPV or IRR? } & 15\end{array}$

1.08 Other Investment Criteria $\quad 19$

1.09 Mutually Exclusive Projects 20

$\begin{array}{ll}1.10 \text { Summary } & 21\end{array}$

1.11 Further Reading $\quad 21$

Chapter II Basic Conventions of Financial Accounting 23

2.01 Principles of Financial Accounting 23

2.02 The Income and Expenditure Statement 24

2.03 The Balance Sheet $\quad 29$

2.04 Sources and Applications of Funds 31

2.05 Integrated Documentation System for Financial Accounting 33

2.06 Use of the System for Financial and Economic Analysis 39

2.07 Further Reading 41

Chapter III Probabilities, Projections, and Investment 42

3.01 Project Appraisal and Forecasting $\quad 42$

3.02 Risk and Uncertainty 43

3.03 Probability Distributions and their Characteristics 44

3.04 Deriving Probability Distributions: An Example 46

3.05 Three Point Distributions $\quad 47$

3.06 Aggregating Probability Distributions 48

3.07 Use of Probabilistic Information in Project Appraisal 51

3.08 Choice under Risk and Uncertainty 53

3.09 Time Series Analysis $\quad 56$

3.10 Explicit Causal Models $\quad 58$

3.11 Further Reading $\quad 59$ 
Chapter IV SCBA: Historical and Analytical Principles 61

$\begin{array}{ll}4.01 \text { Public Sector Investment Planning } & 61\end{array}$

$\begin{array}{ll}4.02 \text { Historical Aspects } & 63\end{array}$

4.03 The Literature of the 1960s $\quad 65$

4.04 The New Methodologies 66

4:05 Efficiency Pricing and the Rationale of the New Methodology 69

4.06 Problems of Pursuing Comparative Advantage 71

4.07 Essentials of the New Methodology: Efficiency Pricing 75

$\begin{array}{ll}4.08 \text { Social Pricing } & 78\end{array}$

$\begin{array}{ll}4.09 \text { Summary } & 79\end{array}$

4.10 Further Reading $\quad 80$

Chapter V Efficiency Pricing and Traded Goods 82

$\begin{array}{ll}5.01 \text { The Application of SCBA } & 82\end{array}$

5.02 Correcting for Trade 'Distortions' 83

5.03 LMST or UNIDO? $\quad 86$

5.04 LMST Terminology and Conventions in More Detail 89

5.05 Problems in the Valuation of Traded Goods (TG) 91

5.06 Traded Goods: Tariffs, Taxes and Domestic Cost Components 93

5.07 Solving for ARs Simultaneously 96

5.08 How Representative are Average ARs? 97

5.09 Summary 98

5.10 Further Reading $\quad 100$

Chapter VI Potentially Traded and Non-Traded Goods 101

$\begin{array}{ll}6.01 \text { Introduction } & 101\end{array}$

6.02 Non-Traded Goods and Services 101

6.03 Valuing Potentially Traded Goods (PTG) 102

6.04 Non-Traded Goods (NTG) and Decomposition 103

6.05 Valuation of Non-Traded Items: An Example 105

6.06 Protectionism and General Equilibrium 107

6.07 The Free Trade Exchange Rate 109

6.08 Labour's Consumption Bundle $\quad 111$

6.09 'Optimal' Protection $\quad 113$

6.10 Some Political Remarks $\quad 114$

$\begin{array}{ll}6.11 \text { Data Sources } & 116\end{array}$

6.12 Further Reading 117

Chapter VII Economic Pricing of Factors of Production 118

$\begin{array}{ll}7.01 \text { Introduction } & 118\end{array}$

$\begin{array}{ll}7.02 \text { Valuing Factors of Production } & 118\end{array}$ 
7.03 The Economic Cost of Unskilled Labour as a Project Input 119

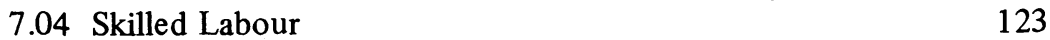

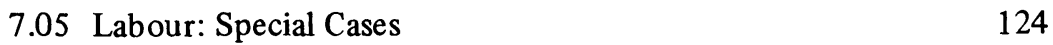

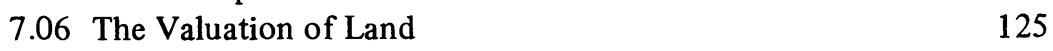

7.07 The Valuation of Capital and the Accounting Rate of Interest 127

7.08 The Effective Cost of Foreign Borrowing 132

$\begin{array}{ll}7.09 \text { Data Sources } & 135\end{array}$

7.10 Further Reading 135

Chapter VIII Social Pricing, Distribution, and the Public Sector 137

$\begin{array}{ll}8.01 \text { Introduction } & 137\end{array}$

8.02 Distribution of Benefits between Nationals and Non-Nationals 138

8.03 Distribution of Benefits between Nationals and SCBA 139

8.04 Weighting Incremental Consumption Benefits 141

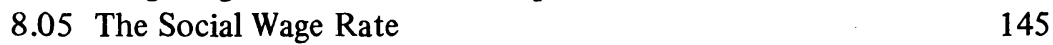

8.06 Choice of Techniques and Macro-Policy Objectives 148

8.07 The Social Accounting Rate of Interest (SARI) 149

8.08 Cross-checking the Value of Public Income (v) 151

8.09 Income Distribution Weights and National Income 153

8.10 Politics, Planning and the New Methodology 155

8.11 Further Reading 159

$\begin{array}{ll}\text { Appendix A } & 163\end{array}$

$\begin{array}{ll}\text { Appendix B } & 231\end{array}$

$\begin{array}{ll}\text { Bibliography } & 239\end{array}$

$\begin{array}{ll}\text { Index } & 249\end{array}$ 


\section{ACKNOWLEDGEMENTS}

I should like to thank a number of people who have made valuable contributions to the book in its present form. First and foremost, I am indebted to my colleague Richard Brown who contributed major parts of Chapter II as well as helping with some of the worked examples in the text and much of the material contained in Appendix A. Pedro Misle Benitez also provided help with worked examples, some of which are drawn from his own Manual on project appraisal used for internal teaching purposes at the Institute of Social Studies. Members of the Institute's staff who provided useful comments on the first draft include Aurora Carreon, Kurt Martin and Paul van der Wel.

I am also indebted to a number of others for comments and suggestions which I have endeavoured to incorporate in the present text; notably Andrew Barnett, Valpy FitzGerald, Stephen Guisinger, John MacArthur, David Pearce. Maurice Scott and John White.

On the production side, particular thanks are due to Jean Sanders, the Institute's Publications Officer, as well as to Kristi Cruzat, Henny Kouwenhoven and Netty Born who saw the manuscript through various stages of typing.

The usual absolution regarding errors and omissions applies. 


\section{INTRODUCTION}

For some years now, one of my obligations has been to give a series of lectures on social cost-benefit analysis. My first lecture normally includes an example of a project to build a bridge which displaces an existing ferry, an example pirated from the Introduction to Richard Layard's book which he took from someone else. In any event, the salient point is that the 'bridge and ferry' lecture in its earliest form distinguished between financial appraisal, in which only toll charges were counted as a benefit, and 'social appraisal' which required explaining such concepts as willingness to pay, consumer surplus, externalities and so forth. As one might expect, building the bridge always turned out to be financially unsound but socially warranted. Since then, however, the bridge and ferry lecture has evolved considerably. There are now at least four different ways of appraising the project: private financial, Government financial, economic and social. Notions of consumer surplus and the like have been supplemented by more advanced technical razzle-dazzle; calculations of accounting ratios, consumption conversion factors, income distribution weights and the like currently extend to several blackboards. Not surprisingly, all the methods yield different answers. To make matters worse, students who once listened attentively asking occasional questions about the meaning of this or that calculation now seem more concerned with the political implications of pursuing trade efficiency and distributional objectives and the role of the public sector within dependent capitalist economies. An ex-student of mine sat in on this year's bridge and ferry lecture and remarked that life was simpler in the old days.

Partly for this reason, the present work is a somewhat unorthodox mixture of didactic exposition, basic theory and political commentary, sacrificing a degree of rigour and elegance in the process. The general structure adopted for the book, as the title suggests, broadly divides the field into sections on methods of financial, economic, and social analysis, moving gradually from elementary discounting techniques with which most readers may be presumed familiar to more complex principles and procedures many of which are still the subject of disagreement in the literature. Unlike traditional cost-benefit texts, welfare theory is here largely eschewed, the salient assumption being that the strategic role of the public sector in setting the rate of accumulation and ensuring equitable distribution through direct intervention in economic 
activity is now so widely accepted - at least in the development literature if not in practice - that the debate as to whether atomistically conceived individual preferences can ever be efficiently aggregated, through the market or otherwise, is now little more than an intellectual curiosum. In this sense cost-benefit analysis is not, as is sometimes suggested, the application of welfare economics, but its successor. Its merit is to successfully conceptualise a hierarchy of price systems in which ruling market prices are accorded lowest status, and the generalised use of social accounting prices is seen as an ultimate objective. By implication, cost-benefit analysis could be argued to be least appropriate in the case of a predominantly capitalist economy, and most appropriate for an advanced socialist economy (in which enterprises enjoy a large measure of autonomy in investment decisions) though such an inference is rarely drawn in the present literature.

Although the book is intended for a wider audience than that of specialists in the subject, notably planners as well as those academics (professional economists or otherwise) who wish to catch up with recent developments in a rapidly expanding field, it focuses predominantly on theory and application of what is termed the 'new methodology', or synthesis of thought which has emerged since the publication of the OECD Marual nearly a decade ago. Accordingly, the first three chapters may be treated as optional reading since these deal with basic discounting and investment criteria, investment appraisal under risk and uncertainty, and the elements of financial accounting. The inclusion of the latter, though somewhat unconventional, is intended to help clarify what is for most economists as obscure an area as is social cost benefit to the business school graduate. The section on discounting and investment criteria sets out what are now broadly accepted conventions basic to all forms of investment appraisal, while the material on risk and uncertainty analysis includes a brief review of elementary statistical principles. Together, these constitute a necessary point of departure for the introductory reader, while those already familiar with the subject matter may find it helpful to briefly review the ground or else move directly to the following chapters.

Chapters IV through VII deal with 'economic' evaluation or, broadly, with the theoretical justification and methodology for transforming ruling market prices into what are sometimes called shadow.prices but which in this book are termed economic accounting prices. Here, current orthodoxy distinguishes between two levels of market price 'distortion', the first arising from protectionist policies in the trade sector working their way through to price relatives in all domestic markets including that for factors, and the second arising from non-trade induced factor market distortions; viz. labour's opportunity cost and the opportunity cost of public funds.

Chapter IV opens with a summary of developments in cost-benefit theory stressing the rise of the new (post-1968) methodology from the fusion of dif- 
ferent currents of thought, notably the neo-classical theory of public finance which is largely concerned with developed capitalist economies, and the postwar development literature with its strong classical emphasis. This is followed by a critical review of the 'trade efficiencv' debate which suggests that while the pursuit of comparative advantage raises many more questions than it answers (viz. assessing comparative advantage in the longer term and minimising adverse effects of trade dependency), the adoption of world prices the Little-Mirrlees proposal - decisively breaks the nexus between production decisions and domestic market forces, hence opening the way to a new round of debate about the role of the public sector in planning the trade and nontrade sectors. Finally, the major features of the Little-Mirrlees, Squire-van der Tak and Marglin-Sen-DasGupta approaches are summarised.

Chapters V and VI deal with the economic pricing of traded and nontraded goods respectively and are essentially a didactic exposition of the synthesis of approaches proposed by Little and Mirrlees and Squire and van der Tak (LMST). Concepts of alternative numéraires, trade distortions, shadow exchange rates, and consumption conversion factors are explained in detail and the UNIDO approach is seen to be a special (second best) case of currently accepted practice. Iterative calculations of accounting ratios for traded and non-traded goods are illustrated by means of numerical examples, the latter being shown to involve problems of principle where non-traded goods are project outputs. The valuation of potentially traded goods is related in the conventional manner to expectations about changes in future trade policies. Concluding sections cover the calculation of elasticities where changed policies are accompanied by devaluation and show the symmetry between the general equilibrium exchange rate approach and the project specific decomposition and conversion approach, and a discussion of 'optimal tax/ tariff' strategy and cartelisation is included.

The economic valuation of factors in terms of opportunity cost is dealt with in Chapter VII, the separation of 'economic' and 'social' parameters (Chapter VIII) being deemed useful for reasons of exposition. This allows an explicit distinction to be made between 'second best' economic valuation (that is to say, where 'social' objectives are ignored) and first best valuation in which economic and social prices coincide because additions to government savings are treated at par with additions to consumption for all income groups or regions. The treatment of labour's foregone output requires an excursion into aspects of labour market theory and alternative positions are reviewed in brief. In discussing capital, attention is first drawn to some wellknown definitional problems, and simple elements of theory are introduced to distinguish notions of time preference, marginal productivity of public and private funds, and the opportunity cost of public finance. The SOC vs. STP debate is introduced as a prelude to the modern 'social' pricing approach, the 
former (SOC) position being shown to be consistent with an essentially conservative view of the role of the public sector and the latter (STP) emphasising Government's role as having ultimate responsibility for determining the rate of accumulation. Since both positions are normative, it can be argued that for the purposes of 'second best' economic valuation the appropriate discount rate is simply whatever rate rations projects in a manner which uses up available public capital. If such a discount rate cannot easily be determined by trial and error, investment ranking criteria $(\mathrm{PV} / \mathrm{K})$ may need to be employed in the initial instance. The chapter concludes with a brief section on measuring the effective cost of overseas public borrowing.

The final chapter deals with social pricing parameters. The Little and Mirrlees (LM) and Squire and van der Tak (ST) consumption weighting procedures are discussed and illustrated, there being some slight difference of approach between the two. The logic of the social wage rate (SWR) is examined and possible refinements noted; the discussion then relates the SWR to choice of techniques and, ultimately, to the choice of sectoral investment strategy. Continuing on the lines of Chapter VII, the ideal public sector discount rate for consumption (CRI), the social discount rate for investment (SARI) and the conditions under which these coincide are discussed in more detail. A section then follows on the relationship between the use of distribution weights at micro-level and welfare assumption implicit in orthodox National Income accounting conventions (which is perhaps the substantive point of Redistribution with Growth), arguing the need for consistency between planning prices at different levels. The chapter closes with a critical examination of the role of the State implicitly assumed in much of the costbenefit literature, the salient argument being that effective realisation of trade efficiency, distribution and growth objectives which are the central concern of the new cost-benefit synthesis, far from having to be incorporated into project evaluation criteria because of constraints on other areas of State power, imply a major extension of public control over key 'surplus generating' activities.

In the accompanying appendices, besides a standard set of discount tables, the reader will find a set of questions and numerical examples accompanied by a limited set of sample answers. These are grouped according to chapter and are intended to make the book more generally useful as an aid to teaching. Finally, one should mention at least some of the things which have been left out. No discussion appears, for instance, of the particular problems associated with the evaluation of sectorally specific projects (viz. industry, agriculture and transport) other than incidentally in some of the textual examples. Nor has it been attempted to deal with a variety of questions which complement project analysis, such as optimal size of plant, optimal location theory, regional investment balance and so on. Perhaps the most important omission 
in this respect is to have treated macro-planning issues in cursory fashion and ignored macro-planning techniques altogether, particularly with respect to how these are used to identify candidate projects. In a different vein, the book is open to the criticism that in having attempted to relate technique to broad political issues, justice has been done to neither. Suffice it to say that I am aware of these limitations and can only hope that these will provide an incentive to readers to take up where I have left off.

Institute of Social Studies

George Irvin

The Hague, March 1977 